\title{
ИССЛЕДОВАНИЕ АНАЛЬГЕТИЧЕСКОЙ АКТИВНОСТИ ДИФАРМАКОФОРОВ НА ОСНОВЕ ИБУПРОФЕНА, ДЕКСИБУПРОФЕНА И НЕБРАЦЕТАМА
}

\section{В.С. Слюсаренко, М.В. Корокин, М.В. Покровский, С.Н. Коваленко}

Белгородский государственный национальный исследовательский университет, ул. Победы, д. 85, г. Белгород, 308015, Российская Федерация

DOI: 10.19163/MedChemRussia2021-2021-462

E-mail: slusarienk092@mail.ru

На сегодняшний день в медицине и фармакологии актуальной является проблема поиска новых фармакологических агентов, обладающих выраженной анальгетической активностью. Мы считаем, что для решения данной задачи оптимальным является применение комбинированной лекарственной терапии для одновременного воздействия на различные точки патогенеза и пути реализации ноцицептивных ощущений. Мы провели изучение анальгетической активности двухдифармакофоров - RIN01086 (включает в себя фармакофоры Ибупрофен и Небрацетам) и RIN02178 (включает в себя фармакофоры Дексибупрофен и Небрацетам) на модели уксусно-кислых корчей, вызванных внутрибрюшинным введением 0,75\% раствора уксусной кислоты. Подсчет числа “корчей” начинали спустя 15 минут после введения уксусной кислоты и проводили в течение следующих 30 минут. RIN01086 и RIN02178 вводили внутрижелудочно, за 30 минут до внутрибрюшинного введения раствора уксусной кислоты в дозе 102 мг/кг, и референсные соединений дексибупрофен, ибупрофен и небрацетамв дозе 51 мг/кг. Эффект учитывали по уменьшению числа “корчей” сравнительно с контрольными нелеченными животными.

Введение дифармакофоров RIN01086 иRIN02178 а также ибупрофена, небрацетама и дексибупрофена в исследуемых дозировках приводило к статистически значимому и в различной степени выраженному уменьшению количества корчей после внутрибрюшинного введения уксусного раствора крысам. Наиболее выраженная анальгетическая активность установлена у дифармакофора RIN02178 Дексибупрофен + Небрацетам (рис. 1).

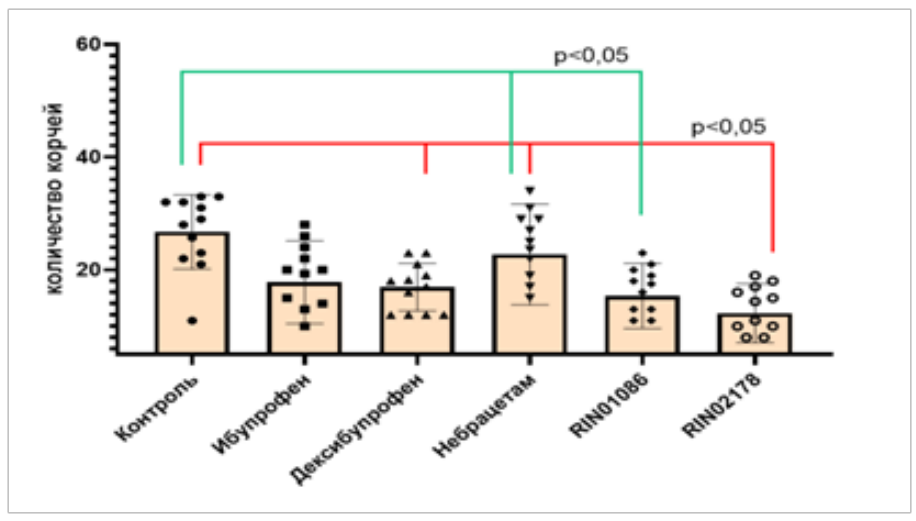

Рис. 1. Влияние дифармакофорных производных уксусной и пропионовой кислот при внутрижелудочном введении на количество корчей, вызванных внутрибрюшинным введением уксусной кислоты. 